\title{
Hellenistic Influence in the Epistle to the Hebrews ${ }^{1}$
}

\section{by Alan M. Fairhurst}

WHEN WE REFER to Hellenistic influence in this connection I assume that we have in mind primarily the influence which derived from Plato. This had obviously been through various phases by the time this epistle was written, and the most likely channel of its communication would have been through the Alexandrian scholar Philo, who died about 50 A.D. He was a great exegete of the Old Testament, but his greatness was somewhat qualified by his desire to find in it a complete philosophical system equal to that of the Greeks. He was a great apologist, but had many of the weaknesses of those who indulge in special pleading. Another possible source of Greek influence could have been the Greek mystery cults, but this is always difficult to assess as we lack accurate documentation.

Amongst those who have written in English on this subject I would accord pride of place to Prof C. K. Barrett's brilliant essay entitled The Eschatology of the Epistle to the Hebrews. ${ }^{2}$ William Manson's book on the epistle, published in I 95 I, ascribes to Hellenistic influence only a limited place. With this position Prof. Barrett is in agreement, although his treatment is far more extensive and detailed. Héring would be far less in agreement. One of the real champions of Hellenistic influence was James Moffatt, whose commentary on the book was published in the International Critical Commentary in 1924. It is easy to underrate the work of Moffatt on this epistle, but it ought never to be despised, for it is supported by weighty

1 Being the substance of a paper read to the New Testament Study Group, July, 1959 .

2 To be found in the volume published in honour of Prof. C. H. Dodd called The background of the New Testament and its eschatology edited by W. D. Davies and D. Daube. This essay was published in 1956 and deserves to be widely known. Another article in the same volume also considers Greek influence. It is by J. Héring, who has also written a commentary on the book in French. 
scholarship. In his introduction Moffatt argues at length his contention that 'the philosophical element in his view of the world and God is fundamentally Platonic.' Westcott in his famous commentary of $\mathrm{r} 889$ is far more guarded and does not commit himself in this direction. Also of crucial importance is Oscar Cullmann's book Christ and Time published in 1945. $\mathrm{He}$ is vigorous in denying Hellenistic influence in this sphere. On the sacramental aspect of the epistle Prof. C. F. D. Moule's book The Sacrifice of Christ and the several works of N. Dimock are relevant. Amongst foreign work on the epistle which bears on the subject of Hellenistic influence the two volumes of Spicq are a mine of information.

Hellenistic influence in the epistle may have affected cosmology, chronology, soteriology, typology, and even Christology. It may significantly have influenced the eschatological framework of the epistle. It has undoubtedly been an influence on the style of the writer. This is such a contrast, in its elegance and polish, to the rest of the New Testament that it is not difficult to agree with Moffatt's analysis of the style in his introduction, at least in its main outline. However it is not the style of the epistle that really concerns us, although it has a bearing on the question of authorship and place of composition. If this could be solved it would of course help enormously in this whole question, but in the absence of any certainty it would be idle to speculate on the extent to which all the possible candidates may have been familiar with Plato and Philo and other Hellenistic influence. Of them all Apollos has the best claim to such acquaintance by virtue of his Alexandrian origin. ${ }^{3}$

Because the epistle is so closely reasoned it is not possible to isolate subjects where there might be Hellenistic influence with any precision; so they will be treated more or less together. The main question is whether Plato's view of the Two Worlds is to be found in the epistle as the dominating influence or not. If it is to be found, as Moffatt found it, we must ask whether it is truly integrated with the eschatology of the writer. Certain passages do suggest a Platonic relationship between Two Worlds. If the Platonic influence was the primary one all the main themes in the epistle would have to show a Platonic

3 Acts xviii. 24. 
relationship of a heavenly type and an earthly antitype. Thus the earthly tabernacle, the sabbath rest, and the holy city would have to be the perfect images of the heavenly sanctuary, the eternal rest and the heavenly city.

Taking the sabbath rest ( $\sigma \alpha \beta \beta \alpha \tau \iota \sigma \mu \sigma^{\prime}$, iv. 9) first we can say that the correspondence between the sabbath and the sabbath rest is not only Platonic, if it is Platonic at all. The main influence would appear to be the Old Testament seen through the eyes of primitive Christian eschatology. Prof. Barrett (op. cit., pp. 366-373) demonstrates that the handling of the Old Testament here is different from both Philo and Barnabas. For the writer the rest is both now in existence and it is to come. By faith it can be entered now (iv. I, 3) and yet it still remains for Christians to strive to enter it (iv. 9-I I). This is in keeping with the whole tenor of New Testament eschatology. For instance we might consider the teaching on the kingdom in the Gospels, which is both present in some sense already, and yet Christians are to pray for its coming. It is evident that the relationship

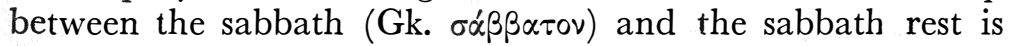
not a straightforward Platonic one if we study iv. I-Io carefully. Here the earthly rest with which the heavenly rest is contrasted is in fact not the sabbath itself ( $\sigma \alpha \beta \beta \alpha \tau o v)$ but the rest ( $\varkappa \alpha \tau \dot{\alpha} \pi \alpha v \sigma \iota \zeta)$ which Joshua had failed to give the people of Israel after their wanderings (iv. 8). This word for rest $(\varkappa \alpha \tau \alpha \dot{\alpha} \pi \alpha \nu \sigma \iota \varsigma)$ is also used for God's rest (iii. I I, I8; iv. I, 3, 4, 5), but it is not a rest of which the sabbath is a copy. It is a rest which God was willing to share with His people, and not merely let them share a copy of it. It was 'my rest' that they could not enter (iii. I I, etc.). So we conclude that although the rest ( $\left.\varkappa \alpha \alpha_{\alpha} \pi \alpha \cup \sigma \iota \zeta\right)$ is linked with God resting the seventh day (iv. 4) and although there remains a sabbath rest ( $\sigma \alpha \beta \beta \alpha \tau o v$; a word which occurs here only in the New Testament, iv. 9) the contrast is not drawn with the actual sabbath ( $\sigma \alpha \beta \beta \alpha \tau o v)$, which would have been very Platonic, but with the entry into the promised land, which was a far more dynamic and eschatological concept.

When we come to the case of the city it is even harder to show an exact Platonic relationship. It is true that the heavenly Jerusalem is spoken of as already existing (xii. 22). It is the 
city of the living God. But the writer does not explicitly speak of the earthly city as being a pattern of this. What he does say is that 'here we have no lasting city but we seek the city which is to come' (xiii. I4). As with the sabbath rest Prof. Barrett (pp. $373 \mathrm{ff}$.) shows that the author's treatment of the city is eschatological. It is both now to be entered (xii. 22) and it is a citywhich is to come and which is sought by pilgrims (xi. I4-I6). Prof. Barrett traces the development of this hope back to exilic times and to Rabbinic literature. This is to be found in the standard works on the subject and references are cited on p. 374 . He points out that while the references are to works which are later than Hebrews 'the notion of a heavenly Jerusalem is early' and this 'is proved beyond doubt by Rev. iii. I2; xxi. 2, IO and especially by Gal. iv. 26, where Paul introduces the "Jerusalem which is from above" with no explanation, assuming the thought to be completely familiar' (p. 375). He goes on to say that although the Jewish sources are silent about the exact relationship 'we may without hesitation conclude that, according to Jewish thought, there exists a heavenly city, of which the present earthly Jerusalem is an inferior copy; and that in the future this heavenly city will in some way be manifested as the Jerusalem of the age to come. This complex dualism is characteristic of apocalyptic, and it is precisely this dualism (and not a Platonic dualism) which appears in Hebrews' (pp. 375 f.).

The heart of the debate centres round the heavenly and the earthly sanctuary, and here there is more support in the text. The main passages are viii. $I-5$ and ix. 23-24. The earthly

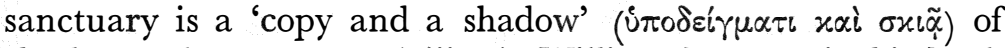
the heavenly sanctuary (viii. 5). William Manson in his book on the epistle sketches the probable background of these passages (pp. I $24 \mathrm{f}$.). The idea of sacrificial worship in heaven was a familiar one in Judaism, from the time when Moses was shown the pattern on the mount. ${ }^{4} \mathrm{He}$ then goes on to say that this idea would be developed at Alexandria under the influence of Plato's doctrine of ideas, especially as set out in the Timaeus, and combined with Jewish midrashic traditions to produce a philosophical and highly edifying exegesis such as we find in

4 Ex. xxv. 40. 
Philo's 'de opificio mundi'. He concludes, 'but while it is right to see in the Alexandrian Jewish theology the background against which the conception of the two worlds in the epistle to the Hebrews is elaborated, it has to be carefully observed that the interests of the writer to the Hebrews are not in cosmology but in redemption, and that his exposition of the heavenly sanctuary is put into entire subservience to his exposition of the sacrifice and atoning work of Jesus within the veil. The element of Alexandrianism does not enter the epistle until this point is reached and is not continued after this point is passed. . . . Not the nature of reality, but the advent of the end is the dominating concern of the writer. For him the eternal world stands essentially in front of us, IMPENDING on us as immediate apocalyptic event, and if he brings in the idea of its present heavenly circumstance, it is because Jesus has already gone into the world of light as our "forerunner" (pp. I24 f.). This seems to be a very fair assessment. Prof. Barrett sums up in a similar fashion: 'the heavenly tabernacle and its ministrations are from one point of view eternal archetypes, from another, they are eschatological events.' (p. 385).

We cannot deny the Hellenistic background usage of words like 'shadow' $(\sigma x \iota \alpha)$ in viii. 5 , 'copy ( $\left.\pi^{\prime} \delta \varepsilon \varepsilon \gamma \mu \alpha\right)$ in viii. 5 and ix. 23 (though it is most interesting to note that attic writers used $\pi \alpha \rho \alpha \delta \varepsilon \varepsilon \gamma \mu \alpha$, cf. Plato Timaeus $37 \mathrm{c}$ where there might

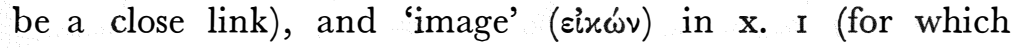
passage Moffatt cites a very similar usage and verbal similarity in Plato's Cratylus 306E). Heavenly realities are 'true' $(\dot{\alpha} \lambda \eta \theta \iota \nu \alpha$ ) ; on earth they are 'copies' ( $\dot{\pi} \pi \circ \delta \varepsilon i \gamma \mu \alpha \tau \alpha)$ or antitype $(\dot{\alpha} v \tau i \tau u \pi \alpha)$ (ix. 23f.).

Again it is the eschatological framework which needs emphasis. As Manson remarks, redemption not cosmology is the overriding interest. And the discussion of sacrifice and its heavenly significance is not Platonic. Moreover, the epistle shows a definite temporal relationship between the earthly and the heavenly sphere, as we have already had occasion to observe in connection with the sabbath rest. In Greek thought it would have been entirely inappropriate to apply categories of time to the heavenly sphere, which was essentially timeless. Not so here. In Hebrews Christ enters the heavenly sphere and sits 
down (i. 3) having made purification for sins. The death of Christ on the earthly sphere is not a manifestation of something which goes on eternally. The writer is careful to point this out in a passage which requires the closest attention. In ix. $24-26$ we are told in the strongest terms that Christ does not offer Himself repeatedly in heaven 'for then $\mathrm{He}$ would have had to suffer repeatedly since the foundation of the world' (ix. 26). His sacrifice once for all ${ }^{5}$ in the sphere of time, although it has eternal validity in that $\mathrm{He}$ offered Himself through the eternal Spirit (ix. I4) (taking this to refer to the Holy Spirit and not to the eternal realm in a Platonic sense, although some do take it thus). This chronological framework, so different from Greek ideas (although not the early Homeric picture where gods and men live in the same time sequence), still awaits its due completion. 'Christ, having been offered once to bear the sins of many, will appear a second time, not to deal with sin but to save those who eagerly await Him' (ix. 28).

Prof. Barrett again shows that Philo and Barnabas treat the Jewish temple and its heavenly counterpart in a way different from Hebrews. Philo speaks of the timeless reality of heaven whereas Barnabas emphasizes the subjective religious experience. Hebrews on the other hand insists on the eschatological act, a thing done in time with objective and corporate consequences' and 'that such an objective and corporate act as he describes was necessary in order to take away the objective and universal guilt of mankind. For him, what lies between heaven and earth, God and man, is not the difference between the phenomena of sense perception and pure being, but the difference between holiness and sin' (p. 388). Sense perception is in fact discussed later in the epistle but there it is in connection with faith (xi. 3). But surely Prof. Barrett is right in his point about sin. In his introduction Moffatt speaks of the writer's profound sense of sin (p. xlv). It is far more likely that it came from the Old Testament than from Plato.

This seems an appropriate place to discuss the chronological question further. The writer is not concerned, as we have seen, with contrasting the earthly time sphere with the timelessness of the heavenly sphere, as Plato does in the Timaeus. Life with

5 Note continual use of $\alpha \dot{\alpha} \alpha \xi$ and $\dot{\varepsilon} \varphi \dot{\alpha} \pi \alpha \xi$ in the epistle. 
God is not a blessed escape from time, as Greek thought conceived it. The things which are eternal are the relationships between God and man and they are entered upon in the time sphere. It is interesting that the word 'eternal' (ai '́vvos) is used with 'salvation' (v. 9) 'Spirit' (ix. I4) 'redemption' (ix. I2) and 'covenant' (xiii. 20). Of these the most difficult reference is that of ix. I 4, which we have already mentioned. Moffatt makes much of this (p. xliii, p. I 24). It is, however, we venture to think, not so much that the writer is emphasizing the fact that the sacrifice was offered in the timeless sphere as the fact that it was eternally valid. The sacrifice was once for all. 'Eternal' draws attention to the fact that it partakes of the very life of God Himself. Thus it does not pass away. The barrier of sin is done away and the way to God lies open for us to approach with boldness (iv. I6).

Cullmann in his book maintains that the Greek view of time does not show itself in the epistle, and that the invisible is thought of in terms of time and not of space (p. 54, Eng. trans.). He maintains that the xalpós concept (one of the Greek words for time, but in the N.T. emphasizing opportunity) is not Hellenistic.

Chronology is notoriously difficult to understand and not all agree with Cullmann, who may well oversimplify with his idea of the 'upward sloping line' to describe Biblical thought in contrast with a 'circle' to describe Greek thought (p. 5I). It is a real problem how something done in a moment of time can have permanent significance. But it is equally clear that we must have adequate safeguards against importing ideas which may be in direct conflict with the argument of the epistle. The use of 'today' in iii. I 3 is difficult but Moffatt shows some very interesting Rabbinic parallels (p. 46). The implication that the present age will pass away is certainly eschatological (ix. 9). The conclusion of the present age will be brought about by the appearance of Christ a second time (ix. 28). Then all things will be put in subjection under His feet (ii. 7-8). The passing away of the present age will be an eschatological event and the writer looks back to Haggai ii. 6 when he writes of it (xii. 26-7). He notes that some things cannot be shaken (xii. 27) but the heavens will be (xii. 26). I am not sure if Plato would have put 
it like that. What is unshakeable is the Kingdom. And that is received now (xii. 28).

The typology of the epistle is a very difficult subject, as is seen by the number of recent publications (e.g. by Grant, Lampe, and Hanson) on this theme in the New Testament. ${ }^{6}$ Perhaps the most interesting piece of typology in the epistle is the treatment of Melchizedek, as a type of Christ. Spicq comments (vol. ii, p. 207) that Philo's interpretation of Genesis xiv may provide a point of departure for the writer, but no more. The handling of the subject is the writer's own, and is very different from that of Philo. One point must be noted. The writer makes use of the argument from silence when dealing with Melchizedek (vii. 3). This was a common practice of Philo, as both Moffatt (pp. 9I f.) and Westcott (p. 2oI, n.I) remark. There are, however, Rabbinic parallels to this. ${ }^{7}$ On the broader level it is very hard to believe that the allegorical intepretation of the scriptures, so popular with Philo, which was rejected by the Jews after his death, did not afford the writer many suggestive ways of using the Old Testament.

However that may be, the important point for our consideration is that the types look forward for the writer (e.g. the law is a shadow of good things to come, $x$. I). They are not like the shadows in the cave in Plato's Republic. As Prof. Barrett writes, 'The shadows in his (the writer's) cave are all shadows of an event that happened once for all, the death of Jesus'. The handling of the high priest theme could never be the same in Hebrews and in Philo because of the clarity with which the writer had grasped the antitype, Jesus Christ. Moffatt admits that the treatment in the two is different (pp. xlvii ff., 38).

The treatment of the high priest theme in Hebrews affects the soteriology of the epistle not a little. In the old tabernacle the altar on which the animals were slain was outside the sanctuary and the Holy of Holies. The altar of incense was itself outside the Holy of Holies ${ }^{8}$ in the Tabernacle as it was

6 Reference should also be made to Daniélou's review of Hanson's book in Theology, July 1959 .

7 As R. A. Stewart points out in his thesis Old Testament Usage in Hebrewes, Philo and Rabbinic writers, pp. 7of.

8 G. Lv. xvi. I 2. 
also later in the Temple. ${ }^{9}$ The writer follows the ritual of the day of Atonement in Lv. xvi as his type. It is therefore inappropriate to speak, as some do, of an altar inside the Holy of Holies on which sacrifice is made, and then to say that this refers to heaven and that therefore Christ is continually sacrificed before the Father. It is true that an altar and a lamb are seen in heaven in Rev. vii and viii, but the Lamb is in the midst of the throne (vii. I7) and the altar is the altar of incense (viii. 3). According to the ritual in Lv. xvi the altar of incense had to be sprinkled with blood together with the holy place itself (xvi. I5, I8). The main difficulty is that the writer to the Hebrews puts the altar of incense inside the Holy of Holies (ix. 4). The author of the Apocalypse, as we have just seen, seems to take it in the same way. This is hard to explain, but even so it does not excuse the loose use of the term 'altar' in sacramental theology today. For it seems often to be associated with the altar of sacrifice. This for the writer to the Hebrews was outside the type and the reality of the sanctuary. Thus the use of the term in liturgy often reveals a gross ignorance of Old Testament ritual and the use made of it by the writer in this epistle. The altar which Ghristians have, to which the writer alludes in xiii. Io is anything but the crude altar of pagans. It is not one from which to eat because, as William Manson says (p. I50), 'the only analogy which the death of Ghrist has with the sacrifices of the past is limited to the whole burnt offering for sin, in which after the blood of the victims was carried by the High Priest into the Holy of Holies, their bodies were totally consumed by fire outside the camp of Israel. ${ }^{10}$ Our altar then is the altar of our Saviour's martyrdom, "outside the camp"'. In any case the idea of Christ still officiating at an altar in heaven, at which $\mathrm{He}$ is still priest and victim, fails to take account of the once for all character of the death in the epistle and the explicit teaching in ix. 26, and also the continual emphasis on Christ's session at the right hand of God. His ministry is now one of intercession. Indeed the altar of incense inside the sanctuary emphasizes this very point. It consecrates our approach to God by His very presence and

9 Lk. i. II.

10 Cf. Lv. xvi. 27. 
by the eternal efficacy of the blood which has been sprinkled (ix. 24). This ministry continues until one day He appears again as the high priest of old to them that wait for Him (ix. 28). Thus it can be seen in the whole treatment of the death of Christ how Biblical the writer is, how unphilosophic and unspeculative, and how unlike the eternal world of Plato's ideas.

Before concluding it should be said that the writer does not appear to be influenced by the Greek mystery cults in any significant way. It is true that he uses terminology that was

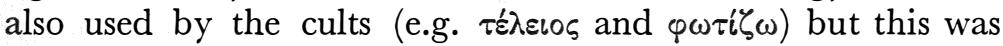
common terminology and used by. others also. Moffatt discounts any such influence, and suggests that the writer felt the same aversion as Philo (p. li), although Philo also on occasion would employ their terminology for his own purposes.

Such also are our conclusions in general about Hellenistic influence in the epistle. Terminology is used which is very reminiscent of Plato's Two Worlds, but the dominating ideas are drawn from other sources. It is not a question of the primitive Christian eschatology being an unfortunate and uncomfortable survivor in a perspective dominated by Plato. It provides the framework and controls the writer's thought. If this is not realized then, as Prof. Barrett concludes 'there can be no guarantee that the unique act of God in the weakness, humility and agony of His Son will remain central, or that the conviction will be maintained that through this act all things were made new and the powers of the age to come were released. But provided that this priority (of eschatological imagery) is maintained, Hebrews itself, as part of the New Testament canon, shows that the language of philosophy may be more serviceable in expressing Christian truth than some Biblical theologians are prepared to allow' (p. 393).

(NOTE. The work of R. A. Stewart in his thesis Old Testament usage in Hebrewes, Philo and Rabbinic writers is to be obtained on request in the Anderson room of the University Library, Cambridge. All rights are reserved by the University. That is why little reference is made to it in this paper. The reference number is M.Lit.b7o. Like Prof. Barrett, the writer stresses the kinship 
with Rabbinic literature in the epistle, especially in view of his regard for the authority of the Old Testament. The whole work is of absolutely fundamental importance, and is particularly good in its treatment of cosmology in Plato, Philo and Hebrews. He sees links with Philo and also differences, but concludes that the key concepts of the epistle are Christian, not Rabbinic or Jewish.) 